Lancet. 2008 April 5; 371(9619): 1200-1210. doi:10.1016/S0140-6736(08)60527-9.

\title{
Premenstrual syndrome
}

\author{
Kimberly Ann Yonkers, MD, \\ Departments of Psychiatry, Epidemiology and Public Health and Obstetrics and Gynecology and \\ Reproductive Science, Yale School of Medicine, CT, USA
}

Prof. P M Shaughn O'Brien, MD, and Keele University Medical School, University Hospital of North Staffordshire, Stoke on Trent, UK

Prof. Elias Eriksson, MD

Department of Pharmacology, Institute of Neuroscience and Physiology, Sahlgrenska Academy, Göteborg University, Sweden

\section{Abstract}

Most women of reproductive age have some physical discomfort or dysphoria in the weeks before menstruation. Symptoms are often mild, but can be severe enough to substantially affect daily activities. About $5-8 \%$ of women thus suffer from severe premenstrual syndrome (PMS); most of these women also meet criteria for premenstrual dysphoric disorder (PMDD). Mood and behavioural symptoms, including irritability, tension, depressed mood, tearfulness, and mood swings, are the most distressing, but somatic complaints, such as breast tenderness and bloating, can also be problematic. We outline theories for the underlying causes of severe PMS, and describe two main methods of treating it: one targeting the hypothalamus-pituitary-ovary axis, and the other targeting brain serotonergic synapses. Fluctuations in gonadal hormone levels trigger the symptoms, and thus interventions that abolish ovarian cyclicity, including long-acting analogues of gonadotropin-releasing hormone ( $\mathrm{GnRH})$ or oestradiol (administered as patches or implants), effectively reduce the symptoms, as can some oral contraceptives. The effectiveness of serotonin reuptake inhibitors, taken throughout the cycle or during luteal phases only, is also well established.

\section{Introduction}

Most women of reproductive age have one or more emotional or physical symptom in the premenstrual phase of the menstrual cycle. The symptoms are mild, but 5-8\% have moderate to severe symptoms that are associated with substantial distress or functional impairment. In early medical reports about this issue, clinically significant premenstrual

Correspondence to: Dr Kimberly Ann Yonkers, Departments of Psychiatry, Epidemiology and Public Health and Obstetrics and Gynecology and Reproductive Science, Yale School of Medicine, 142 Temple Street, Suite 301, New Haven, CT 06510, USA Kimberly.Yonkers@yale.edu.

\section{Conflict of interest statement}

Between 2004 and 2006, KAY provided a consultation to Wyeth and Berlex; received honoraria from Wyeth and Berlex that was less than $\$ 10000$ annually; received grants from Berlex, Wyeth, and medication to support a small study from GlaxoSmithKline and from Pfizer; grants from the National Institutes of Health, the National Association for Research in Schizophrenia and Affective Disorders, and the Federal Health Resources Services Administration; received an honorarium in 2007 for a lecture from Berlex; and receives continued grants from Wyeth (ongoing since 2006) and from the National Institutes of Health and the National Association for Research in Schizophrenia and Affective Disorders. Between 2004 and 2007, PMSO'B provided consultations to Bayer Schering and TAP Pharmaceuticals; received research grants from Bayer Schering, Wyeth, GlaxoSmithKline, Beecham, and Lilly; received honoraria from Bayer Schering totally less than £5000; and received grants from the British Heart Foundation and North Staffordshire Medical Institute. EE has received research grants from Lundbeck and Bristol Myers Squibb, and has provided consultations to Schering, Lundbeck, and Lilly. 
symptoms were named premenstrual tension (PMT) ${ }^{1}$ or premenstrual syndrome (PMS). ${ }^{2}$ The WHO International Classification of Diseases (ICD) includes "premenstrual tension syndrome" under the heading "Diseases of the Genitourinary Tract". However, like PMS and PMT, this description is not useful for the purpose of clinical diagnostics, drug labelling, or research, since it is not defined by specific criteria, and does not specify severity.

\section{Diagnosis}

In the mid-1980s, a multidisciplinary US National Institutes of Health consensus conference on PMS proposed criteria that were adopted by the Diagnostic and Statistical Manual III $(\mathrm{DSM} \text { III })^{3}$ to define the severe form of this condition. Originally entitled "late luteal phase dysphoric disorder", it was later renamed "premenstrual dysphoric disorder" (PMDD). The diagnosis of PMDD stipulates (1) the presence of at least five luteal-phase symptoms (panel), at least one of which must be a mood symptom (ie, depressed mood, anxiety or tension, affect lability, or persistent anger and irritability); (2) two cycles of daily charting to confirm the timing of symptoms; and (3) evidence of functional impairment. Finally, symptoms must not be the exacerbation of another psychiatric condition. ${ }^{4}$

A problem with the PMDD diagnosis is that many women with clinically significant premenstrual symptoms do not meet full diagnostic criteria; they might not have a prominent mood symptom or the five different symptoms required as a minimum by DSM IV. The American College of Obstetrics and Gynecology (ACOG) has attempted to rectify this situation by defining moderate to severe PMS; the criteria are the presence of at least one psychological or physical symptom that causes significant impairment and is confirmed by means of prospective ratings. 5

Despite differences between diagnostic systems, women with clinically significant PMS described in scientific reports usually correspond to those with a diagnosis of PMDD. Accordingly, in this Seminar, we use the term PMS to mean severe variants of premenstrual discomfort such as those that would meet the ACOG and most PMDD criteria. It is important to note, however, that some clinicians and researchers question whether all symptoms occurring in the premenstrual phase should be regarded as parts of a single syndrome. This is because although there is general agreement that all symptoms are triggered by fluctuations in sex steroids, and thus abolished when hormonal cyclicity ends, there is no evidence that the symptoms share a common pathophysiological factor, such as an aberration in sex steroid production.

\section{Prevalence}

Most studies on the prevalence of premenstrual complaints are based on retrospective reports which, by their nature, can introduce recall bias. ${ }^{6-12}$ However, the findings of these studies are consistent with those from the few epidemiological studies that used prospective symptom ratings. ${ }^{13,14}$ Findings of prospective and retrospective studies suggest that 5-8\% of women with hormonal cycles have moderate to severe symptoms. However, some studies suggest that up to $20 \%$ of all women of fertile age have premenstrual complaints that could be regarded as clinically relevant. ${ }^{15}$

\section{Pattern of symptom expression}

The length of symptom expression varies between a few days and 2 weeks (figure 1). Symptoms often worsen substantially 6 days before, and peak at about 2 days before, menses start. ${ }^{16,17}$ Anger and irritability are the most severe complaints and start slightly earlier than other symptoms (figure 2) ${ }^{16}$ It is not uncommon for symptoms to linger into the 
next menstrual cycle ${ }^{16-18}$ but, by definition, there must be a symptom-free interval before ovulation. Typically, women have the same set of symptoms from one cycle to the next. ${ }^{19}$

Several patterns of true or apparent comorbidity can occur in a woman with premenstrual symptoms. First, she might have another psychiatric disorder at another point in her life (lifetime comorbidity). Second, she might have an ongoing psychiatric or general medical condition and concurrent premenstrual symptoms that are not part of the co-occurring disorder (concurrent comorbidity). Third, she might have an ongoing psychiatric or general medical condition that becomes worse premenstrually-usually defined as premenstrual exacerbation. ${ }^{4,20}$

Estimates for lifetime comorbidity between PMS and other mood disorders range from $30 \%$ to $70 \% .^{12,21-23}$ This prevalence is higher than one would expect, even taking into consideration that mood disorders are common in women (at least 30\% of women have a minor or major depressive disorder at some point in their lives); estimates of comorbidity, however, might be inflated because of an overlap in symptoms. It is notable that the risk of developing perimenopausal depression ${ }^{24}$ and postnatal depression ${ }^{25,26}$ has been reported to be higher in women who have PMS, leading some to suggest that these different conditions share a vulnerability to changes in gonadal steroid concentrations.

Anxiety disorders also occur at a higher rate in women with PMS. ${ }^{27,28}$ Women with PMS, like those with panic disorder (but in contrast to those with other mood disorders), have an increased tendency to panic when exposed to panicogenic agents such as lactate and carbon dioxide, suggesting that panic disorder and PMS share certain pathophysiological mechanisms. ${ }^{27,28}$

\section{Aetiology and pathophysiology}

Since most women of reproductive age report at least mild premenstrual symptoms, a certain degree of discomfort during the luteal phase should probably be considered physiological rather than pathological. In evolutionary terms ${ }^{29}$ luteal mood changes could be remnants of the oestrous cycle-related fluctuations in behaviour shown by lower species with the original purpose of promoting reproduction: sexual receptivity being increased and aggression decreased when oestrogen is high before ovulation. ${ }^{30-32}$ Although aggression in rodents and other animals might not be entirely equivalent to irritability and anger in human beings, such cycle-related variations in behaviour seem likely to be related to cycle-related variations in behaviour in women.

In this context, one should consider the fact that, historically, repeated pregnancies, lactation, or malnourishment led to extended periods of amenorrhoea, a situation that has changed by advances in nutrition and with our capacity to control reproduction. ${ }^{33}$ The result is that women today have much longer periods of cyclic fluctuations of oestrogen and progesterone with associated premenstrual symptoms. ${ }^{33}$

Since the most characteristic feature of PMS is the relation between symptom appearance and menstrual cyclicity, researchers have long suggested that gonadal steroids are involved in the pathophysiology. ${ }^{1}$ In line with this notion, symptoms are absent during non-ovulatory cycles, ${ }^{34}$ abolished by ovariectomy ${ }^{35-37}$ or treatment with ovulation inhibitors, ${ }^{38-41}$ and reinstated by administration of exogenous hormones. ${ }^{42-45}$

How changes in sex steroid production provoke luteal symptoms, however, remains to be understood. Many researchers suggest that premenstrual complaints are elicited by the drop in progesterone concentrations in the late luteal phase, and link this to changes in CNS neurotransmitters such as $\gamma$-aminobutyric acid (GABA). ${ }^{46,47}$ This theory is, however, 
challenged by the fact that many women have symptoms that start at ovulation and during the early luteal phase-ie, before the fall in progesterone has started.

Moreover, for women in whom the endogenous hormonal cyclicity had been abolished by pretreatment with an agonist of gonadotropin-releasing hormone $(\mathrm{GnRH})$, daily progesterone administration for a month provoked symptoms (with some delay), despite hormone concentrations remaining stable. ${ }^{45}$ Also, if a luteal decrease in progesterone was the precipitating factor, administration of progesterone during this phase would be an effective treatment, which it is not. ${ }^{48}$ The alternative hypothesis, that symptoms are triggered by the preovulatory peak in oestradiol, or by the postovulatory increase in progesterone, or both, ${ }^{45,49}$ thus seems more likely. This theory does not explain, however, why symptoms begin with ovulation for some women but late into the luteal phase for others.

The importance of progesterone compared with oestrogen in triggering symptoms is equally unclear. Mood change reported by postmenopausal women taking sequential hormone replacement therapy suggests that progesterone, rather than oestrogen, is responsible for inducing dysphoria; ${ }^{42,50}$ moreover, oestrogen exerts an antidepressant effect in women with perimenopausal depression. ${ }^{51}$ Of note, the days of the cycle during which symptoms are likely to appear are those in which progesterone dominates over oestrogen. On the other hand, oestradiol has been reported to be as effective as gestagen in provoking PMS-like complaints, ${ }^{45}$ and the oestrogen component of hormone replacement therapy can enhance gestagen-induced dysphoria. ${ }^{52}$ Moreover, luteal administration of oestrogen has been reported to aggravate premenstrual symptoms, ${ }^{53}$ and luteal administration of an oestrogen antagonist reduces premenstrual mastalgia. ${ }^{54}$

Evidence suggests that women with and without PMS do not differ with respect to the production of gonadal steroids, ${ }^{55}$ indicating that PMS might instead be associated with enhanced responsive ness to normal, fluctuating concentrations of these hormones. In line with this, administration of exogenous gonadal steroids provoked PMS-like symptoms after pretreatment with an ovulation inhibitor in women with PMS, but not in controls. ${ }^{45}$

Such an enhanced tendency to have disphoria as a reult of the effects of sex steroids on the brain might be heritable, as suggested by twin studies. ${ }^{56-58}$ Other possible risk factors for PMS are high body-mass index, ${ }^{59}$ stress, ${ }^{7}$ and traumatic events. ${ }^{60}$

With respect to hormones other than the sex steroids, thyroid indices are reported to be more variable in women with PMS than in controls. ${ }^{61,62}$ Moreover, as in anxiety and mood disorders, changes in circadian rhythms have been noted in PMS. Some studies thus suggest that the absolute levels of hormones such as melatonin, cortisol, thyroid-stimulating hormone, and prolactin are not altered but that the timing of their excretion might be aberrant in women with PMS. ${ }^{63}$

\section{Central neurotransmission in PMS}

Since mood and behavioural symptoms are key features of PMS, underlying mechanisms must involve the brain. Indeed, sex steroids easily pass the blood-brain barrier, and sex steroid receptors are abundant in many brain regions that regulate emotions and behaviour, including the amygdala and the hypothalamus.

The brain neurotransmitter serotonin is implicated in the regulation of mood and behaviour, partly because of observations made in preclinical studies, and partly because of the antidepressant and anxiety-reducing effects exerted by serotonin-facilitating drugs in human 
beings. This notion has also gained support from genetic studies ${ }^{64,65}$ and from brain imaging experiments. 66

The most clear-cut change in rodents exposed to serotonin depletion is an increase in aspects of behaviour that are dependent on sex steroids-ie, aggression and sexual activity, suggesting that a major physiological role for serotonin is to modulate or dampen sexsteroid-driven behaviour. ${ }^{31,67}$ Consistent with this, reduced libido is probably the most common side-effect of long-term treatment with serotonin reuptake inhibitors (SRIs). ${ }^{68,69}$

Sex steroids have been shown to modulate serotonin transmission in rodents ${ }^{70-72}$ and nonhuman primates, ${ }^{73}$ indicating that gonadal hormones influence behaviour partly by interacting with serotonergic transmission. Alternatively, serotonin terminals could exert a dampening influence on brain areas, such as the amygdala, that are under a parallel, independent activating influence of sex steroids.

The importance of serotonin for the regulation of mood and aggression, and the probable role of serotonin in modulating sex-steroid-driven behaviour, suggest that serotonin could be involved in the pathophysiology of PMS. Support for this theory is provided by three sources of evidence. First, premenstrual symptoms are effectively dampened not only by SRIs (see below), but also by other serotonin-enhancing treatments, such as serotoninreleasing agents, ${ }^{74,75}$ a serotonin precursor, ${ }^{76}$ and a serotonin-receptor agonist. ${ }^{77}$ Second, impairment in serotonergic transmission achieved by a tryptophan-free diet, ${ }^{78}$ or by treatment with a serotonin-receptor antagonist, ${ }^{79}$ provokes symptoms. Third, various indices of serotonergic trans mission are reported to be aberrant in women with PMS. ${ }^{75,80-89}$

Another neurotransmitter that has been linked to PMS is the inhibitory aminoacid GABA. This theory gains support from an imaging study, ${ }^{90}$ the fact that some progesterone metabolites interact with GABA A receptor, ${ }^{46,47}$ and the observation that women with PMS seem to differ from controls with respect to the responsiveness of this receptor complex. ${ }^{91}$ To what extent women with PMS have an abnormal production of GABA-A-modulating progesterone metabolites, however, is a matter of controversy, ${ }^{92-94}$ and whether modulation of GABA A activity can relieve symptoms is unclear. ${ }^{95}$ Moreover, much of the work implicating GABA in the pathophysiology of PMS is based on the assumption that premenstrual complaints are due to progesterone withdrawal, a notion that has been questioned. Notably, there are important interactions between GABAergic and serotonergic neurons; ${ }^{96,97}$ a theory implicating GABA in the pathophysiology of PMS is thus not in conflict with the serotonin hypothesis. Further, several SRIs, which have therapeutic benefit for PMS, also have profound effects on enzymes involved in the production of progesterone metabolites that modulate GABA A receptors. ${ }^{98,99}$

\section{Pathophysiology of somatic symptoms}

It remains unclear whether premenstrual somatic symptoms-such as breast tenderness, bloating, and joint and muscle pain—result from reduced tolerance to physical discomfort while in a dysphoric mood state, or are caused by changes in hormone-responsive tissues in the periphery. Studies have failed to confirm fluid retention or breast enlargement in women reporting these symptoms; ${ }^{100,101}$ moreover, treatment aimed at influencing brain neurotransmission - eg, the SRIs - exerts at least some palliative effect on somatic symptoms. On the other hand, the dopamine D2 receptor agonist, bromocriptine, ${ }^{102,103}$ or chasteberry, ${ }^{104}$ which lower serum concentrations of prolactin, are effective for the treatment of premenstrual mastalgia, but not for mood symptoms. Likewise, a specific effect on premenstrual mastalgia could be achieved by luteal administration of danazol ${ }^{105}$ or an oestrogen-receptor antagonist. ${ }^{54}$ 
Results of some early studies suggest the involvement of aldosterone ${ }^{106}$ or deoxycorticosterone, a progesterone metabolite and aldosterone agonist, ${ }^{33,106}$ in the pathophysiology of premenstrual bloating. Given that severe abdominal bloating occurs in the absence of weight gain, any theory related to water retention is, however, called into doubt. Many believe that premenstrual headache, migraine, and epilepsy should not be regarded as part of PMS, but as separate conditions. Notably, SRIs have no effect on premenstrual headache. Painful menstrual bleeding (dysmenorrhoea), endometriosis, and menopausal symptoms are often confused with PMS, ${ }^{107}$ but they are separate and must be clearly distinguished as such in research and in the clinic environment.

\section{Treatment}

Before pharmacological treatment is considered, the medical history of women with presumed PMS should be investigated for conditions such as depression, dysthymic disorder, anxiety disorders, and hypothyroidism. Given the possible links between PMS and sexual abuse, as well as with post-traumatic stress disorder, ${ }^{60}$ a history that assesses the presence of these factors, as well as domestic violence, should be obtained. Some individuals with anxiety and mood disorders, including PMS, attempt to cope with symptoms by using alcohol or illicit drugs, although these substances can provoke or worsen dysphoria and anxiety. Thus, the possible use of such substances should be addressed during the evaluation.

The diagnosis of PMS (according to ACOG criteria) and PMDD requires daily charting of symptoms over two menstrual cycles; various methods have been developed for this purpose, such as the Daily Record of Severity of Problems. ${ }^{108}$ A woman with severe symptoms, however, might not be willing to accept the delay in treatment involved with such recording. However, the benefit for the patient and the clinician is that it enables a clear diagnostic distinction between PMS/PMDD on the one hand, and premenstrual exacerbation of an underlying psychiatric disorder, or a condition with no relation to the menstrual cycle, on the other.

Many treatment regimens have been touted as effective for PMS, but few are supported by clinical evidence. Since effective treatments do not necessarily reduce all symptoms equally, assessing improvement using summary scales that evaluate change in many symptoms could obscure a specific effect on a particular symptom. Given that some medications might work better for particular symptoms, treatment should be individualised according to the symptom profile.

\section{Serotonin reuptake inhibitors (SRIs)}

Many clinical trials evaluating the efficacy of an SRI for the management of PMS/PMDD have shown benefit, ${ }^{109}$ the response rate usually being $60-90 \%$ for active treatment versus $30-40 \%$ for placebo. ${ }^{110}$ SRIs that have been shown effective are the serotonergic tricyclic antidepressant clomipramine, ${ }^{111,112}$ the selective SRIs citalopram, ${ }^{113}$ escitalopram, ${ }^{114}$ fluoxetine, ${ }^{115-120}$ paroxetine, ${ }^{121-125}$ and sertraline, ${ }^{126-130}$ and the serotonin and noradrenaline reuptake inhibitor venlafaxine (table). ${ }^{131,132}$ SRIs reduce both mood symptoms and somatic complaints, and they also improve quality of life and social functioning. ${ }^{122,140,141}$ Many believe that SRIs should be regarded as first-line treatment in PMS patients with severe mood symptoms. ${ }^{142,143}$

SRIs are more effective for PMS than are anti-depressants that predominantly affect noradrenergic transmission, ${ }^{115,121,133}$ implying that the effect of SRIs in PMS is not merely an antidepressant effect. This notion is also supported by the fact that the beneficial effect of SRIs for PMS begins rapidly, whereas the antidepressant effect is slow in onset. The fast 
onset of action in PMS renders intermittent treatment, from midcycle to menses, a feasible alternative to continuous therapy. ${ }^{12,113,119,120,125,127,128,134,144}$ Data suggest that even briefer periods of active treatment are more effective than placebo. ${ }^{124,145}$

Clinical experience suggests that most but not all women with PMS prefer intermittent treatment to continuous. SRIs administered intermittently, however, seem less effective for somatic symptoms than for mood symptoms, ${ }^{119,120,125,146}$ and less effective for somatic symptoms than is continuous treatment. ${ }^{125}$

Side-effects of SRIs are usually mild. Nausea is very common during the first days of treatment, but vanishes after a few days. It usually does not reappear, even when the treatment is intermittent. ${ }^{125}$ Reduced libido and anorgasmia are not uncommon, and often persist for the duration of treatment, ${ }^{69}$ but are not present during the drug-free intervals of intermittent treatment. SRIs are not addictive, but many individuals experience discontinuation symptoms when they stop medication abruptly. ${ }^{16}$ When SRIs are used intermittently, discontinuation symptoms are seldom a problem, suggesting that 2 weeks is too short an exposure period to elicit withdrawal symptoms. ${ }^{113,117,124}$

SRIs are approved for PMDD in the USA, Canada, and Australia, but not in Europe. The lack of a European consensus on diagnostic criteria and terminology for PMS/PMDD probably accounts in part for the fact that the European Agency for the Evaluation of Medicinal Products (EMEA) withdrew the existing licence for fluoxetine in four European countries (including the UK). They argued that there is no sharp borderline between mild PMS and PMDD, and that approval of an SRI for PMDD might lead to unwarranted medication in mild cases. Additionally, they said, PMDD is a condition that could go on for years, and that long-term trials would be needed to assess long-term tolerability. However, these same arguments could be, but have not been, applied to other long-lasting conditions — such as generalised anxiety disorder, social phobia, and dysthymic disorder-for which SRIs are approved in Europe and for which it is equally true that there is no sharp borderline between mild and severe variants.

\section{Other psychoactive drugs}

Other CNS-acting drugs tested for use in PMS do not seem to be particularly effective. Whereas lithium ${ }^{147}$ and non-serotonergic antidepressants ${ }^{121,133,148}$ have been completely ineffective, the serotonergic 5HT1-A agonist buspirone ${ }^{77,149}$ exerts weak beneficial effects. For the high-affinity benzodiazepine, alprazolam, efficacy data are conflicting, ${ }^{95,150-152}$ alprazolam can, however, be a helpful adjunctive treatment for women who identify premenstrual insomnia or overwhelming anxiety as important symptoms. Treatment with alprazolam should be monitored carefully because of the risk of dependence, particularly if the individual has a history of substance abuse.

\section{Hormonal interventions}

Given the involvement of sex steroids in the triggering of premenstrual symptoms, many regard treatments that target these hormones as the most rational approach for reducing premenstrual complaints. We emphasise, however, that there is no support for the long-held view that PMS is due to progesterone deficiency; accordingly, attempts to treat PMS by progesterone $^{48}$ (or with oestrogen ${ }^{53}$ ) in the luteal phase have been unsuccessful. Progesterone is nevertheless approved as treatment of PMS in the UK, and is still being used —usually in the form of pessaries—as first-line treatment by many general practitioners. ${ }^{153}$

The rationale behind the hormonal treatment of PMS is thus not simply to correct a hormonal abnormality, but to interrupt the normal hypothalamus-pituitary-gonadal cyclicity 
that is triggering the symptoms. This can be achieved by administering a long-acting $\mathrm{GnRH}$ agonist. ${ }^{38-41}$ There is persuasive evidence that these preparations are extremely effective. They are, however, relatively invasive since they result in a "medical menopause", which is accompanied by typical menopausal symptoms, particularly flushing, as well as a risk of osteoporosis if the therapy is prolonged. These side-effects, entirely due to the oestrogen deficiency, can be prevented by oestrogen replacement, combined with a gestagen to prevent oestrogen-induced endometrial hyperplasia (table). Whereas some patients report returning symptoms when given gestagens, ${ }^{44}$ a meta-analysis suggests that this option is nevertheless often feasible. ${ }^{41}$ A promising alternative is to combine a GnRH agonist with continuous administration of tibolone, a synthetic oestrogen, progestogen and androgen receptor agonist. ${ }^{41,154}$

Another way of avoiding gestagen-induced reappearance of symptoms is to administer gestagens locally in the form of a levonorgestrel-containing intrauterine system; systemic hormone concentrations via this route of administration are negligible once the endometrium has become atrophic. Only very limited evidence is available to support this approach, but clinical experience is widespread.

Other methods to inhibit ovarian cyclicity, such as surgical bilateral oophorectomy (which can be undertaken laparoscopically), also abolish PMS. ${ }^{35,36,155}$ As with treatment with longacting GnRH agonists, oophorectomy requires hormonal add-back with oestrogen plus gestagens. If bilateral oophorectomy and hysterectomy are combined, oestrogen can be used alone. Surgical therapy tends to be too invasive an approach for most patients with PMS. However, patients who have a separate gynaecological disorder requiring hysterectomy usually must consider removal or conservation of the ovaries. Conservation of the ovaries is nearly always advised in younger women-however, if a patient has debilitating PMS, conservation of the ovaries might be inadvisable, and the patient could request that her ovaries are removed. Although no research evidence is available to support this, administration of a GnRH agonist for 2-3 months before surgery will show the patient the probable effect of removing the ovaries and could inform her decision.

Administration of oestrogen at doses that inhibit ovulation ${ }^{135,137}$ is one of the simplest ways to effectively abolish PMS symptoms. Oral therapy is not usually advised; instead oestrogen administered as a transdermal patch ${ }^{135}$ or subcutaneous implant ${ }^{136,156}$ has been recommended (table). Doses are usually higher than are those required for hormone replacement treatment, but lower than for the oral contraceptive pill; for patches, 100, 150, or $200 \mu \mathrm{g}$ could be necessary. Unless the patient has had a hysterectomy, she will need to be given a progestagen to prevent endometrial hyperplasia. This could result in restimulation of PMS in some patients, unless it is administered within a progesterone-containing levonorgestrel-containing intrauterine system. Although there is clear-cut evidence that oestrogen suppresses both ovulation and symptoms, and there is good evidence that the intrauterine system prevents hyperplasia, evidence for the use of this combination as treatment for PMS is limited. ${ }^{157,158}$

Many clinicians use oral contraceptives to manage PMS, but placebo-controlled studies have been few and mostly negative. ${ }^{159,160}$ Since women taking oral contraceptives might have more hormone-related symptoms during the 7-day hormone-free interval than during hormone ingestion, ${ }^{161}$ and since shortening of the hormone-free interval reduces such complaints, ${ }^{162}$ oral contraceptives with few hormone-free days might also be of value for PMS. In line with this, studies show efficacy of a novel oral contraceptive with a hormonefree interval of 4 rather than 7 days. ${ }^{138,139}$ In part, the therapeutic benefit of this oral contraceptive, however, could be a result of the gestagen component, drospirenone, exerting anti-aldosterone and antiandrogen effects. 
The synthetic androgen and gonadotropin inhibitor danazol, when administered at doses that block ovulation, is effective for PMS; ${ }^{163-165}$ however, hirsutism and risk of teratogenicity preclude its use as a first-line agent. Danazol administered at low doses in the luteal phase of the cycle only is not effective for the general symptoms of PMS but for the management of mastalgia and with minimal side-effects. ${ }^{105}$ Luteal administration of an oestrogen receptor antagonist ${ }^{54}$ also reduces mastalgia.

\section{Other treatments}

Possible alterations in circadian rhythmicity ${ }^{63}$ suggest that bright light treatment might be effective for moderate to severe PMS. One controlled study ${ }^{166}$ suggests benefit for this intervention, but it is not clear how long the possible therapeutic effects persist.

The aldosterone antagonist spironolactone seems to be effective for symptoms of bloating and breast pain in PMS, ${ }^{106,167,168}$ although the link between premenstrual somatic symptoms and water retention is questionable.

Most studies assessing the therapeutic effect of vitamin B6 (pyridoxine) in PMS had several methodological limitations, including lack of prospective ratings. Definitive conclusions regarding efficacy cannot be drawn, but a quantitative review suggested that B6 has benefit over placebo. ${ }^{169}$ Calcium supplements could be helpful for women with PMS, ${ }^{135}$ as could Vitex agnus-castus (chasteberry), which is claimed to have antiprolactin effects. ${ }^{170}$ The use of evening primrose oil has been popularised but seems to be ineffective. ${ }^{171}$ Several studies have assessed the therapeutic benefit of magnesium treatment and some, ${ }^{172}$ but not all, ${ }^{173}$ have found it effective. However, these studies have been small and are not definitive; moreover, magnesium can be poorly tolerated.

Although books and magazine articles for the lay public have touted the benefit of restricting sugar and eating multiple small meals as management of PMS, there is little support for these strategies. On the other hand, studies of diets that increase the relative intake of complex carbohydrates suggest benefit, which might be due to an enhanced transport of the serotonin precursor tryptophan into the brain, leading to a transient increase in the synthesis of this transmitter. ${ }^{174,175}$ Cognitive behavioural therapy ${ }^{176}$ and exercise ${ }^{177}$ have also has been claimed to be beneficial.

Various other treatments have been assessed in PMS, but cannot yet be regarded as evidence-based because the studies were not controlled, were flawed, or their findings not replicated. The non-steroidal anti-inflammatory medications mefenamic acid ${ }^{178}$ and naproxen, ${ }^{179}$ as well as the opioid receptor blocker naltrexone ${ }^{180}$ are among these.

\section{Conclusions}

There is substantial empirical research to support the existence of a severe premenstrual disorder causing marked functional impairment. Severe PMS is consistently reported by about $5 \%$ of all women of fertile age. The management of PMS is complex. At the outset it is important to establish a precise diagnosis and not rely on the patient's own diagnosis. It is mandatory to separate PMS/PMDD from other diagnoses, particularly depression and anxiety disorders, premenstrual exacerbation of another disorder, or mild physiological symptoms requiring no more than reassurance; preferably this assessment should be done by the general practitioner before referral to a gynaecologist or a psychiatrist. Diagnosis is best achieved through daily rating symptoms over at least one menstrual cycle; clinicians can ask patients to choose their worst symptoms and chart the severity daily, or can select a validated scale such as the Daily Record of Severity of Problems. The disappearance of symptoms after menstruation is the key to diagnosis. PMS does not seem to be due to 
abnormal concentrations of sex steroids, but the symptoms are triggered by fluctuations of such hormones, the difference between patients and controls probably being that patients are more sensitive to such fluctuations. With respect to brain function, the transmitters serotonin and GABA have been implicated in the underlying mechanism. Treatments inhibiting ovulation, such as GnRH analogues, oestrogen, and certain new oral contraceptives, effectively reduce the symptoms, as do treatment with SRIs, which by some institutions are regarded as first-line agents in severely affected patients.

\section{References}

1. Frank R. The hormonal causes of premenstrual tension. Arch Neurol Psychiatry. 1931; 26:1053-57.

2. Greene R, Dalton K. The premenstrual syndrome. BMJ. 1953; 1:1007-14. [PubMed: 13032605]

3. American Psychiatric Association. Diagnostic and statistical manual of mental disorders-DSM-III. 3. Washington DC: American Psychiatric Association; 1980.

4. American Psychiatric Association. Diagnostic and statistical manual of mental disorders-DSM-IV. 4. Washington DC: American Psychiatric Association; 1994.

5. ACOG. ACOG practice bulletin: premenstrual syndrome. Int J Gynecol Obstet. 2001; 73:183-91.

6. Johnson SR, McChesney C, Bean JA. Epidemiology of premenstrual symptoms in a nonclinical sample-I: Prevalence, natural history and help-seeking behavior. J Repro Med. 1988; 33:340-46.

7. Deuster P, Adera T, South-Paul J. Biological, social, and behavioral factors associated with premenstrual syndrome. Arch Fam Med. 1999; 8:122-28. [PubMed: 10101982]

8. Ramacharan S, Love EJ, Fick GH, Goldfien A. The epidemiology of premenstrual symptoms in a population based sample of 2650 urban women. J Clin Epidemiol. 1992; 45:377-81. [PubMed: 1569434]

9. Woods NF, Most A, Dery GK. Prevalence of perimenstrual symptoms. Am J Public Health. 1982; 72:1257-64. [PubMed: 6889817]

10. Andersch B, Wendestam C, Hahn L, Ohman R. Premenstrual complaints. Prevalence of premenstrual symptoms in a Swedish urban population. J Psychosom Obstet Gynaecol. 1986; 5:39-49.

11. Angst J, Sellaro R, Merikangas KR, Endicott J. The epidemiology of perimenstrual psychological symptoms. Acta Psychiatr Scand. 2001; 104:110-16. [PubMed: 11473504]

12. Wittchen H, Becker E, Lieb R, Krause P. Prevalence, incidence and stability of premenstrual dysphoric disorder in the community. Psychol Med. 2002; 32:119-132. [PubMed: 11883723]

13. Rivera-Tovar AD, Frank E. Late luteal phase dysphoric disorder in young women. Am J Psychiatry. 1990; 147:1634-36. [PubMed: 2244641]

14. Soares C, Cohen L, Otto M, Harlow B. Characteristics of women with premenstrual dysphoric disorder (PMDD) who did or did not report history of depression: a preliminary report from the Harvard study of moods and cycles. J Women's Health Gend Based Med. 2001; 10:873-78.

15. Borenstein J, Dean B, Endicott J, et al. Heath and economic impact of the premenstrual syndrome. J Reprod Med. 2003; 48:515-24. [PubMed: 12953326]

16. Pearlstein T, Yonkers K, Fayyad R, Gillespie J. Pretreatment pattern of symptom expression in premenstrual dsyphoric disorder. J Affect Disord. 2005; 85:275-82. [PubMed: 15780697]

17. Meaden PM, Hartlage SA, Cook-Kerr J. Timing and severity of symptoms associated with the menstrual cycle in a community-based sample in the Midwestern United States. Psychiatr Res. 2005; 134:27-36.

18. Sternfeld B, Swindle R, Chawla A, Long S, Kennedy S. Severity of premenstrual symptoms in a health maintenance organization population. Obstet Gynecol. 2002; 99:1014-24. [PubMed: 12052592]

19. Bloch M, Schmidt PJ, Rubinow DR. Premenstrual syndrome: Evidence for symptom stability across cycles. Am J Psychiatry. 1997; 154:1741-46. [PubMed: 9396955]

20. Steiner M, Born L. Diagnosis and treatment of premenstrual dysphoric disorder: an update. Int Clin Psychopharmacol. 2000; 15 (suppl 3):S5-17. [PubMed: 11195269] 
21. Pearlstein TB, Frank E, Rivera-Tovar A, Thoft JS, Jacobs E, Mieczkowski TA. Prevalence of axis I and axis II disorders in women with late luteal phase dysphoric disorder. J Affect Disord. 1990; 20:129-34. [PubMed: 2148327]

22. Halbreich U, Endicott J. Relationship of dysphoric premenstrual changes to depressive disorder. Acta Psychiatrica Scandinavica. 1985; 71:331-38. [PubMed: 4039877]

23. Mackenzie TB, Wilcox K, Baron H. Lifetime prevalence of psychiatric disorders in women with perimenstrual difficulties. J Affect Disord. 1986; 10:15-19. [PubMed: 2939119]

24. Richards M, Rubinow DR, Daly RC, Schmidt PJ. Premenstrual symptoms and perimenopausal depression. Am J Psychiatry. 2006; 163:133-37. [PubMed: 16390900]

25. Studd JWW, Smith RNJ. Estrogens and depression in women. Menopause: J North Am Menopause Soc. 1994; 1:33-37.

26. Bloch M, Schmidt PJ, Danaceau M, Murphy J, Nieman L, Rubinow DR. Effects of gonadal steroids in women with a history of postpartum depression. Am J Psychiatry. 2000; 157:924-30. [PubMed: 10831472]

27. Landen M, Eriksson E. How does premenstrual dysphoric disorder relate to depression and anxiety disorders? Depress Anxiety. 2003; 17:122-29. [PubMed: 12768646]

28. Yonkers KA. Anxiety symptoms and anxiety disorders: How are they related to premenstrual disorders. J Clin Psychiatry. 1997; 58:62-67. [PubMed: 9133494]

29. Rosseinsky DR, Debonnel PG. An evolutionary theory of premenstrual tension. Lancet. 1974; 2:1024. [PubMed: 4138262]

30. Rapkin AJ, Pollack DB, Raleigh MJ, Stone B, McGuire MT. Menstrual cycle and social behavior in vervet monkeys. Psychoneuroendocrinology. 1995; 20:289-97. [PubMed: 7777657]

31. Ho H-P, Olsson M, Westberg L, Melke J, Eriksson E. The serotonin reuptake inhibitor fluoxetine reduces sex steroid-related aggression in female rats: an animal model of premenstrual irritability? Neuropsychopharmacology. 2001; 24:502-10. [PubMed: 11282250]

32. Hyde J, Sawyer TF. Estrous cycle fluctuations in aggressiveness of house mice. Horm Behav. 1977; 9:290-95. [PubMed: 565333]

33. MacDonald PC, Dombroski RA, Casey ML. Recurrent secretion of progesterone in large amounts: An endocrine/metabolic disorder unique to young women? Endocrine Rev. 1991; 12:372-401. [PubMed: 1760994]

34. Hammarback S, Ekholm U-B, Backstrom T. Spontaneous anovulation causing disappearance of cyclical symptoms in women with the premenstrual syndrome. Acta Endocrinologica. 1991; 125:132-37. [PubMed: 1897330]

35. Casper RF, Hearn MT. The effect of hysterectomy and bilateral oophorectomy in women with severe premenstrual syndrome. Am J Obstet Gynecol. 1990; 162:105-09. [PubMed: 2301479]

36. Casson P, Hahn PM, Van Vugt DA, Reid RL. Lasting response to ovariectomy in severe intractable premenstrual syndrome. Am J Obstet Gynecol. 1990; 162:99-105. [PubMed: 2301523]

37. Cronje WH, Vashisht A, Studd JWW. Hysterectomy and bilateral oophorectomy for severe premenstrual syndrome. Hum Reprod. 2004; 19:2152-55. [PubMed: 15229203]

38. Muse KN, Cetel NS, Futterman LA, Yen SSC. The premenstrual syndrome: Effects of "medical ovariectomy”. N Engl J Med. 1984; 311:1345-49. [PubMed: 6387488]

39. Bancroft J, Boyle H, Warner P, Fraser HM. The use of an LHRH agonist, buserelin, in the longterm management of premenstrual syndromes. Clin Endocrinol. 1987; 27:171-82.

40. Hammarback S, Backstrom T. Induced anovulation as treatment of premenstrual tension syndrome: a double-blind cross-over study with GnRH-agonist versus placebo. Acta Obstet Gynecol Scand. 1988; 67:159-66. [PubMed: 3140572]

41. Wyatt KM, Dimmock PW, Ismail KMK, Jones PW, O'Brien PMS. The effectiveness of GnRHa with and without 'add-back' therapy in treating premenstrual syndrome: a meta analysis. BJOG: Int J Obstet Gynaecol. 2004; 111:585-93.

42. Magos AL, Brewster E, Singh R, O'Dowd T, Brincat M, Studd JWW. The effects of norethisterone in postmenopausal women on oestrogen replacement therapy: a model for the premenstrual syndrom. BJOG. 1986; 93:1290-96. 
43. Henshaw C, Foreman D, Belcher J, Cox J, O’Brien S. Can one induce premenstrual symptomatology in women with prior hysterectomy and bilateral oophorectomy? J Psychosom Obstet Gynecol. 1996; 17:21-28.

44. Leather AT, Studd JW, Watson NR, Holland EF. The treatment of severe premenstrual syndrome with goserelin with and without "add-back" estrogen therapy: a placebo-controlled study. Gynecol Endocrinol. 1999; 13:48-55. [PubMed: 10368798]

45. Schmidt PJ, Nieman LK, Danaceau MA, Adams LF, Rubinow DR. Differential behavioral effects of gonadal steriods in women with and in those without premenstrual syndrome. N Engl J Med. 1998; 338:209-16. [PubMed: 9435325]

46. Smith SS, Ruderman Y, Frye C, Homanics G, Yuan M. Steroid withdrawal in the mouse results in anxiogenic effects of 3alpha, 5beta-THP: a possible model of premenstrual dysphoric disorder. Psychopharmacology. 2005; 29:1-11.

47. Sundstrom Poromaa I, Smith S, Gulinello M. GABA receptors, progesterone and premenstrual dysphoric disorder. Arch Women Ment Health. 2003; 6:23-41.

48. Wyatt K, Dimmock P, Jones P, Obhrai M, O’Brien S. Efficacy of progesterone and progestogens in management of premenstrual syndrome: systematic review. BMJ. 2001; 323:776-81. [PubMed: 11588078]

49. Schmidt PJ, Nieman LK, Grover GN, Muller KL, Merriam GR, Rubinow DR. Lack of effect of induced menses on symptoms in women with premenstrual syndrome. N Engl J Med. 1991; 324:1174-79. [PubMed: 2011161]

50. Hammarback S, Backstrom T, Holst J, von Schoultz B, Lyrenas S. Cyclical mood changes as in the premesntrual tension syndrome during sequential estrogen-progestagen posmenopausal replacement therapy. Acta Obstet Gynecol Scand. 1985; 64:393-97. [PubMed: 4061059]

51. Schmidt PJ. Depression, the perimenopause, and estrogen therapy. Ann NY Acad Sci. 2005; 1052:27-40. [PubMed: 16024748]

52. Bjorn I, Sundstrom-Poromaa I, Bixo M, Nyberg S, Backstrom G, Backstrom T. Increase of estrogen dose deteriorates mood during progestin phase in sequential hormonal therapy. J Clin Endocrinol Metab. 2003; 88:2026-30. [PubMed: 12727949]

53. Dhar V, Murphy BEP. Double-blind randomized crossover trial of luteal phase estrogens (Premarin) in the premenstrual syndrome (PMS). Psychoneuroendocrinology. 1991; 15:489-93. [PubMed: 1966304]

54. Oksa S, Luukkaala T, Maenpaa J. Toremifene for premenstrual mastalgia: a randomised, placebocontrolled crossover study. BJOG. 2006; 113:713-18. [PubMed: 16709215]

55. Rubinow D, Schmidt P. The neuroendocrinology of menstrual cycle mood disorders. Ann N Y Acad Sci. 1995; 771:648-59. [PubMed: 8597438]

56. Condon JT. The premenstrual syndrome: A twin study. Br J Psychiatry. 1993; 162:481-86. [PubMed: 8481739]

57. Kendler KS, Karkowski LM, Corey LA, Neale MC. Longitudinal population-based twin study of retrospectively reported premenstrual symptoms and lifetime major depression. Am J Psychiatry. 1998; 155:1234-40. [PubMed: 9734548]

58. Treloar S, Heath A, Martin N. Genetic and environmental influences on premenstrual symptoms in an Australian twin sample. Psychol Med. 2002; 32:25-38. [PubMed: 11883728]

59. Masho SW, Adera T, South-Paul J. Obesity as a risk factor for premenstrual syndrome. J Psychosom Obstet Gynaecol. 2005; 26:33-39. [PubMed: 15962720]

60. Perkonigg A, Yonkers K, Pfister H, Lieb R, Wittchen HU. Risk factors for premenstrual dysphoric disorder in a community sample of young women: The role of traumatic events and posttraumatic stress disorder. J Clin Psychiatry. 2004; 65:1314-22. [PubMed: 15491233]

61. Girdler SS, Pedersen CA, Light KC. Thyroid axis function during the menstrual cycle in women with premenstrual syndrome. Psychoneuroendocrinol. 1995; 20:395-403.

62. Schmidt PJ, Grover GN, Roy-Byrne PP, et al. Thyroid function in women with premenstrual syndrome. J Clin Endocrinol Metab. 1993; 76:671-74. [PubMed: 8445024]

63. Parry BL, Newton RP. Chronobiological basis of female-specific mood disorders. Neuropsychopharmacology. 2001; 25 (suppl 5):S102-08. [PubMed: 11682284] 
64. Hariri AR, Mattay VS, Tessitore A, et al. Serotonin transporter genetic variation and the response of the human amygdala. Science. 2002; 297:400-03. [PubMed: 12130784]

65. Caspi A, Sugden K, Moffitt TE, et al. Influence of life stress on depression: Moderation by a polymorphism in the 5-HTT gene. Science. 2003; 301:386-89. [PubMed: 12869766]

66. Parsey RV, Hastings RS, Oquendo MA, et al. Lower serotonin transporter binding potential in the human brain during major depressive episodes. Am J Psychiatry. 2006; 163:52-58. [PubMed: 16390889]

67. Eriksson E, Andersch B, Ho HP, Landen M, Sundblad C. Diagnosis and treatment of premenstrual dysphoria. J Clin Psychiatry. 2002; 63 (suppl 7):16-23. [PubMed: 11995774]

68. Gregorian RS, Golden KA, Bahce A, Goodman C, Kwong WJ, Khan ZM. Antidepressant-induced sexual dysfunction. Ann Pharmacother. 2002; 36:1577-89. [PubMed: 12243609]

69. Sundblad C, Wikander I, Andersch B, Eriksson E. A naturalistic study of paroxetine in premenstrual syndrome: efficacy and side effects during ten cycles of treatment. Eur Neuropsychopharmacology. 1997; 7:201-06.

70. Carlsson M, Carlsson A. A regional study of sex differences in rat brain serotonin. Prog NeuroPsychopharmacol Biol Psychiatry. 1988; 12:53-61.

71. Hiroi R, McDevitt RA, Neumaier JF. Estrogen selectively increases tryptophan hydroxylase-2 mRNA expression in distinct subregions of rat midbrain raphe nucleus: association between gene expression and anxiety behavior in the open field. Biol Psychiatry. 2006; 60:288-95. [PubMed: 16458260]

72. Rubinow DR, Schmidt PJ, Roca CA. Estrogen-serotonin interactions: implications for affective regulation. Biol Psychiatry. 1998; 44:839-50. [PubMed: 9807639]

73. Bethea CL, Lu NZ, Gundlah C, Streicher JM. Diverse actions of ovarian steroids in the serotonin neural system. Front Neuroendocrinol. 2002; 23:41-100. [PubMed: 11906203]

74. Brzezinski AA, Wurtman JJ, Wurtman RJ, Gleason R, Greenfield J, Nader T. d-fenfluramine suppresses the increased calorie and carbohydrate intakes and improves the mood of women with premenstrual depression. J Am Coll Obstet Gynecol. 1990; 76:296-300.

75. Su T-P, Schmidt PJ, Danaceau M, Murphy DL, Rubinow DR. Effect of menstrual cycle phase on neuroendocrine and behavioral responses to the serotonin agonist m-chlorophenylpiperazine in women with premenstrual syndrome and controls. J Clin Endocrinol Metab. 1997; 82:1220-28. [PubMed: 9100599]

76. Steinberg S, Annable L, Young S, Liyanage N. A placebo-controlled clinical trial of L-tryptophan in premenstrual dysphoria. Biol Psychiatry. 1999; 45:313-20. [PubMed: 10023508]

77. Landen M, Eriksson O, Sundblad C, Andersch B, Naessen T, Eriksson E. Compounds with affinity for serotonergic receptors in the treatment of premenstrual dysphoria: a comparison of buspirone, nefazodone and placebo. Psychopharmacology. 2001; 155:292-98. [PubMed: 11432692]

78. Menkes DB, Coates DC, Fawcett JP. Acute tryptophan depletion aggravates premenstrual syndrome. J Affect Disord. 1994; 32:37-44. [PubMed: 7798465]

79. Roca C, Schmidt P, Smith M, Danaceau M, Murphy D, Rubinow D. Effects of metergoline on symptoms in women with premenstrual dysphoric disorder. Am J Psychiatry. 2002; 159:1876-81. [PubMed: 12411222]

80. Bancroft J, Cook A, Davidson D, Bennie J, Goodwin G. Blunting of neuroendocrine responses to infusion of L-tryptophan in women with perimenstrual mood change. Psychol Med. 1991; 21:30512. [PubMed: 1876635]

81. Eriksson O, Wall A, Marteinsdottir I, et al. Mood changes correlate to changes in brain serotonin precursor trapping in women with premenstrual dysphoria. Psychiatry Res. 2006; 146:107-16. [PubMed: 16515859]

82. Fitzgerald M, Malone KM, Li S, et al. Blunted serotonergic response to fenfluramine challenge in premenstrual dysphoric disorder. Am J Psychiatry. 1997; 154:556-58. [PubMed: 9090347]

83. Halbreich U, Tworek H. Altered serotonergic activity in women with dysphoric premenstrual syndromes. Int J Psychiatry Med. 1993; 23:1-27. [PubMed: 8514462]

84. Rojansky N, Halbreich U, Zander K, Barkai A, Goldstein S. Imipramine receptor binding and serotonin uptake in platelets of women with premenstrual changes. Gynecol Obstet Investig. 1991; 31:146-52. [PubMed: 1649111] 
85. Steege JF, Stout AL, Knight BS, Nemeroff CB. Reduced platelet tritium-labeled imipramine binding sites in women with premenstrual syndrome. Am J Obstet Gynecol. 1992; 167:168-72. [PubMed: 1442921]

86. Rasgon N, McGuire M, Tanavoli S, Fairbanks L, Rapkin A. Neuroendocrine response to an intravenous L-tryptophan challenge in women with premenstrual syndrome. Fertil Steril. 2000; 73:144-49. [PubMed: 10632430]

87. Steiner M, LNY, Coote M, Wilkins A, Lepage P. Serotonergic dysfunction in women with pure premenstrual dysphoric disorder: is the fenfluramine challenge test still relevant. Psychiatry Res. 1999; 87:107-15. [PubMed: 10579544]

88. Yatham L, Barry S, Dinan TG. Serotonin receptors, buspirone, and premenstrual syndrome. Lancet. 1989; 1:1447-48. [PubMed: 2567451]

89. Melke J, Westberg L, Landen M, et al. Serotonin transporter gene polymorphisms and platelet [3H] paroxetine binding in premenstrual dysphoria. Psychoneuroendocrinology. 2003; 28:446-58. [PubMed: 12573307]

90. Epperson CN, Haga K, Mason GF, et al. Cortical gamma-aminobutyric acid levels across the menstrual cycle in healthy women and those with premenstrual dysphoric disorder: A proton magnetic resonance spectroscopy study. Arch Gen Psychiatry. 2002; 59:851-58. [PubMed: 12215085]

91. Sundstrom I, Ashbrook D, Backstrom T. Reduced benzodiazepine sensitivity in patients with premenstrual syndrome: a pilot study. Psychoneuroendocrinol. 1997; 22:25-38.

92. Schmidt PJ, Purdy RH, Moore PH, Paul SM, Rubinow DR. Circulating levels of anxiolytic steroids in the luteal phase in women with premenstrual syndrome and in control subjects. J Clin Endocrinol Metab. 1994; 79:1256-60. [PubMed: 7962316]

93. Rapkin AJ, Morgan M, Goldman L, Brann DW, Simone D, Mahesh VB. Progesterone metabolite allopregnanolone in women with premenstrual syndrome. Obstet Gynecol. 1997; 90:709-14. [PubMed: 9351749]

94. Girdler S, Straneva P, Light K, Pederson C, Morrow A. Allopregnanolone levels and reactivity to mental stress in premenstrual dysphoric disorder. Biol Psychiatry. 2001; 49:788-97. [PubMed: 11331087]

95. Schmidt PJ, Grover GN, Rubinow DR. Alprazolam in the treatment of premenstrual syndrome: a double-blind, placebo-controlled trial. Arch Gen Psychiatry. 1993; 50:467-73. [PubMed: 8498881]

96. Bhagwagar Z, Wylezinska M, Taylor M, Jezzard P, Matthews PM, Cowen PJ. Increased brain GABA concentrations following acute administration of a selective serotonin reuptake inhibitor. Am J Psychiatry. 2004; 161:368-70. [PubMed: 14754790]

97. Sundstrom I, Backstrom T. Citalopram increases pregnanolone sensitivity in patients with premenstrual syndrome: an open trial. Psychoneuroendocrinology. 1998; 23:73-88. [PubMed: 9618754]

98. Pinna G, Costa E, Guidotti A. Fluoxetine and norfluoxetine stereospecifically and selectively increase brain neurosteroid content at doses that are inactive on 5-HT reuptake. Psychopharmacology (Berl). 2006; 186:362-72. [PubMed: 16432684]

99. Griffin LD, Mellon SH. Selective serotonin reuptake inhibitors directly alter activity of neurosteroidogenic enzymes. Proc Natl Acad Sci USA. 1999; 96(13):512-17.

100. Faratian B, Gaspar A, O’Brien PM, Johnson IR, Filshie GM, Prescott P. Premenstrual syndrome: weight, abdominal swelling, and perceived body image. Am J Obstet Gynecol. 1984; 150:20004. [PubMed: 6540990]

101. Andersch B, Hahn L, Andersson M, Isaksson B. Body water and weight in patients with premenstrual tension. BJOG. 1978; 85:546-50.

102. Andersch B. Bromocriptine and premenstrual symptoms: a survey of double blind trials. Obstet Gynecol Surv. 1983; 38:643-46. [PubMed: 6358978]

103. Ylostalo P, Kauppila A, Puolakka J, Ronnberg L, Janne O. Bromocriptine and norethisterone in the treatment of premenstrual syndrome. J Am Coll Obstet Gynecol. 1981; 58:292-98. 
104. Wuttke W, Jarry H, Christoffel V, Spengler B, Seidlova-Wuttke D. Chaste tree (Vitex agnuscastus)—pharmacology and clinical indications. Phytomedicine. 2003; 10:348-57. [PubMed: 12809367]

105. O'Brien P, Abukhalil I. Randomized controlled trial of the management of premenstrual syndrome and premenstrual mastalgia using luteal phase-only danazol. Am J Obstet Gynecol. 1999; 180:18-23. [PubMed: 9914571]

106. O’Brien PM, Craven D, Selby C, Symonds EM. Treatment of premenstrual syndrome by spironolactone. BJOG. 1979; 86:142-47.

107. Bancroft J, Rennie D. Perimenstrual depression: its relationship to pain, bleeding, and previous history of depression. Psychosom Med. 1995; 57:445-52. [PubMed: 8552735]

108. Endicott J, Nee J, Harrison W. Daily record of severity of problems (DRSP): reliability and validity. Arch Womens Ment Health. 2006; 9:41-49. [PubMed: 16172836]

109. Wyatt KM, Dimmock PW, O’Brien PMS. Selective serotonin reuptake inhibitors for premenstrual syndrome. Cochrane Database of Syst Rev. 2003; 3:CD001396.

110. Yonkers, KA.; Clark, RH.; Trivedi, MH. The psychopharmacological treatment of nonmajor mood disorders. In: Rush, AJ., editor. Mood disorders: systematic medication managementmodern problems of pharmacopsychiatry. 2. Basel: Karger; 1997. p. 146-66.

111. Sundblad C, Modigh K, Andersch B, Eriksson E. Clomipraine effectively reduces premenstrual irritability and dysphoria: a placebo-controlled trial. Acta Psychiatr Scand. 1992; 85:39-47. [PubMed: 1546547]

112. Sundblad C, Hedberg MA, Eriksson E. Clomipramine administered during the luteal phase reduces the symptoms of premenstrual syndrome: a placebo-controlled trial. Neuropsychopharmacology. 1993; 9:133-45. [PubMed: 8216696]

113. Wikander I, Sundblad C, Andersch B, et al. Citalopram in premenstrual dysphoria: is intermittent treatment during luteal phases more effective than continuous medication throughout the menstrual cycle? J Clin Psychopharmaocol. 1998; 18:390-98.

114. Eriksson E, Nissbrandt H, Sörvik K, et al. Esictalopram in the trestment of premenstrual dysphoric disorder. Eur Neuropsychopharmacol. 2005; 15 (suppl 3):S636.

115. Pearlstein TB, Stone AB, Lund SA, Scheft H, Zlotnick C, Brown WA. Comparison of fluoxetine, buproprion, and placebo in the treatment of premenstrual dysphoric disorder. J Clin Psychopharmacol. 1997; 17:261-65. [PubMed: 9241004]

116. Steiner M, Steinberg S, Stewart D, et al. Fluoxetine in the treatment of premenstrual dysphoria. N Engl J Med. 1995; 332:1529-34. [PubMed: 7739706]

117. Stone AB, Pearlstein TB, Brown WA. Fluoxetine in the treatment of late luteal phase dysphoric disorder. J Clin Psychiatry. 1991; 52:290-93. [PubMed: 2071558]

118. Wood SH, Mortola JF, Chan Y-F, Moossazadeh F, Yen SSS. Treatment of premenstrual syndrome with fluoxetine: a double-blind, placebo-controlled, crossover study. Obstet Gynecol. 1992; 80:339-44. [PubMed: 1495689]

119. Cohen L, Miner C, Brown E, et al. Premenstrual daily fluoxetine for premenstrual dysphoric disorder: a placebo-controlled, clinical trial using computerized diaries. Obstet Gynecol. 2002; 100:435-44. [PubMed: 12220761]

120. Miner C, Brown E, McCray S, Gonzales J, Wohlreich M. Weekly luteal phase dosing with enteric-coated fluoxetine $90 \mathrm{mg}$ in premenstrual dysphoric disorder: a randomized, double-blind, placebo-controlled clinical trial. Clin Ther. 2002; 24:417-33. [PubMed: 11952025]

121. Eriksson E, Hedberg MA, Andersch B, Sundblad C. The serotonin reuptake inhibitor paroxetine is superior to the noradrenaline reuptake inhibitor maprotiline in the treatment of premenstrual syndrome. Neuropsychopharmacology. 1995; 12:167-76. [PubMed: 7779245]

122. Cohen L, Soares C, Yonkers K, Bellew K, Bridges I, Steiner M. Paroxetine controlled release for premenstrual dysphoric disorder: a double-blind, placebo-cont rolled trial. Psychosom Med. 2004; 66:707-13. [PubMed: 15385695]

123. Steiner M, Hirschberg A, Bergeron R, Holland F, Gee M, VanErp E. Luteal phase dosing with paroxetine controlled release (CR) in the treatment of premenstrual dysphoric disorder. Am J Obstet Gynecol. 2005; 193:352-60. [PubMed: 16098854] 
124. Yonkers KA, Holthausen GA, Poschman K, Howell HB. Symptom-onset treatment for women with premenstrual dysphoric disorder. J Clin Psychopharmacol. 2006; 26:198-202. [PubMed: 16633152]

125. Landen M, Nissbrandt H, Allgulander C, Sorvik K, Ysander C, Eriksson E. Placebo-controlled trial comparing intermittent and continuous paroxetine in premenstrual dysphoric disorder. Neuropsychopharmacology. 2007; 32:153-61. [PubMed: 17035933]

126. Freeman E, Rickels K, Sondheimer S, Polansky M. Differential reponse to antidepressants in women with premenstrual syndrome/premenstrual dysphoric disorder: a randomized controlled trial. Arch Gen Psychiatry. 1999; 56:932-39. [PubMed: 10530636]

127. Halbreich U, Smoller JW. Intermittent luteal phase sertraline treatment of dysphoric premenstrual syndrome. J Clin Psychiatry. 1997; 58:399-402. [PubMed: 9378691]

128. Jermain DM, Preece CK, Sykes RL, Kuehl TJ, Sulak PJ. Luteal phase sertraline treatment for premenstrual dysphoric disorder: results of a double-blind, placebo-controlled, crossover study. Arch Fam Med. 1999; 8:328-32. [PubMed: 10418540]

129. Young SA, Hurt PH, Benedek DM, Howard RS. treatment of premenstrual dysphoric disorder with sertraline during the luteal phase: a randomized, double-blind, placebo-controlled crossover trial. J Clin Psychiatry. 1998; 59:76-80. [PubMed: 9501889]

130. Freeman E, Rickels K, Sondheimer S, Polansky M, Xiao S. Continuous or intermittent dosing with sertraline for patients with severe premenstrual syndrome or premenstrual dysphoric disorder. Am J Psychiatry. 2004; 161:343-51. [PubMed: 14754784]

131. Freeman E, Rickels K, Yonkers K, et al. Venlafaxine in the treatment of premenstrual dysphoric disorder. Obstet Gynecol. 2001; 98:737-44. [PubMed: 11704162]

132. Cohen L, Soares C, Lyster A, Cassano P, Brandes M, Leblanc G. Efficacy and tolerability of premenstrual use of venlafaxine (flexible dose) in the treatment of premenstrual dysphoric disorder. J Clin Psychopharmacol. 2004; 24:540-43. [PubMed: 15349012]

133. Freeman EW, Rickels K, Sondheimer SJ, Polansky M. Differential response to antidepressants in women with premenstrual syndrome/premenstrual dysphonic disorder: a randomised controlled trial. Arch Gen Psychiatry. 1999; 56:932-39. [PubMed: 10530636]

134. Halbreich U, Bergeron R, Yonkers K, Freeman E, Stout A, Cohen L. Efficacy of intermittent, luteal phase sertraline treatment of premenstrual dysphoric disorder. Obstet Gynecol. 2002; 100:1219-29. [PubMed: 12468166]

135. Watson NR, Studd JW, Savvas M, Garnett T, Baber RJ. Treatment of severe premenstrual syndrome with oestradiol patches and cyclical oral norethisterone. Lancet. 1989; 2:730-32. [PubMed: 2570971]

136. Magos AL, Brincat M, Studd JW. Treatment of the premenstrual syndrome by subcutaneous estradiol implants and cyclical oral norethisterone: placebo-controlled study. BMJ. 1986; 292:1629-33. [PubMed: 3087550]

137. Thys-Jacobs S, Starkey P, Bernstein D, Tian J. Calcium carbonate and the premenstrual syndrome: effects on premenstrual and menstrual symptoms. Premenstrual Syndrome Study Group. Am J Obstet Gynecol. 1998; 179:444-52. [PubMed: 9731851]

138. Yonkers K, Brown C, Pearlstein T, Foegh M, Sampson-Landers C, Rapkin A. Efficacy of a new low-dose oral contraceptive with drospirenone in premenstrual dysphoric disorder. Obstet Gynecol. 2005; 106:492-501. [PubMed: 16135578]

139. Pearlstein T, Bachmann G, Zacur H, Yonkers K. Treatment of premenstrual dysphoric disorder with a new drospirenone-containing oral contraceptive formulation. Contraception. 2005; 72:414-21. [PubMed: 16307962]

140. Pearlstein T, Halbreich U, Batzar E, et al. Psychosocial functioning in women with premenstrual dysphoric disorder before and after treatment with sertraline or placebo. J Clin Psychiatry. 2000; 61:101-09. [PubMed: 10732657]

141. Steiner M, Brown E, Trzepacz P, et al. Fluoxetine improves functional work capacity in women with premenstrual dysphoric disorder. Arch Women's Ment Health. 2003; 6:71-77.

142. Eriksson E, Endicott J, Andersch B, et al. New perspectives on the treatment of premenstrual syndrome and premenstrual dysphoric disorder. Arch Women's Ment Health. 2002; 4:111-19. 
143. Steiner M, Pearlstein T, Cohen LS, et al. Expert guidelines for the treatment of severe PMS, PMDD, and comorbidities: the role of SSRIs. J Women's Health. 2006; 15:57-69.

144. Young SA, Hurt PH, Benedeck DM, Howard RS. Treatment of PDD with sertraline during the luteal phase: a randomised, double-blind, placebo controlled crossover trial. J Clin Psychiatry. 1998; 59:76-80. [PubMed: 9501889]

145. Freeman E, Sondheimer S, Sammel M, Ferdousi T, Lin H. A preliminary study of luteal phase versus symptom-onset dosing with escitalopram for premenstrual dysphoric disorder. J Clin Psychiatry. 2005; 66:769-73. [PubMed: 15960573]

146. Steiner M, Romano S, Babcock S, et al. The efficacy of fluoxetine in improving physical symptoms associated with premenstrual dysphoric disorder. Br J Obstet Gynaecol. 2001; 108:462-68.

147. Steiner M, Haskett RF, Osmun JN, Carroll BJ. Treatment of premenstrual tension with lithium carbonate. A pilot study. Acta Psychiatrica Scand. 1980; 61:96-102.

148. Pearlstein TB, Stone AB, Lund SA, Scheft H, Zlotnick C, Brown WA. Comparison of fluoxetine, bupropion, and placebo in premenstrual dysphoric disorder. J Clin Psychopharmacol. 1997; 17:261-66. [PubMed: 9241004]

149. Rickels K, Freeman E, Sondheimer S. Buspirone in treatment of premenstrual syndrome. Lancet. 1989; 4:777. [PubMed: 2564578]

150. Smith S, Rinehart JS, Ruddock VE, Schiff I. Treatment of premenstrual syndrome with alprazolam: Results of a double-blind, placebo-controlled, randomized crossover clinical trial. Obstet Gynecol. 1987; 70:37-43. [PubMed: 3299178]

151. Harrison WM, Endicott J, Nee J. Treatment of premenstrual dysphoria with alprazolam. Arch Gen Psychiatry. 1990; 47:270-75. [PubMed: 2407209]

152. Freeman EW, Rickels K, Sondheimer SJ, Polansky M. A double-blind trail of oral progesterone, alprazolam, and placebo in treatment of severe premenstrual syndrome. JAMA. 1995; 274:5157. [PubMed: 7791258]

153. Wyatt KM, Dimmock PW, Frischer M, Jones PW, O’Brien SP. Prescribing patterns in premenstrual syndrome. BMC Womens Health. 2002; 2:4. [PubMed: 12086594]

154. Di Carlo C, Palomba S, Tommaselli G, Guida M, Sardo ADS, Nappi C. Use of leuprolide acetate plus tibolone in the treatment of severe premenstrual syndrome. Fertil Steril. 2001; 75:380-84. [PubMed: 11172843]

155. Cronje W, Studd J. Premenstrual syndrome and premenstrual dysphoric disorder. Prim Care. 2002; 29:1-12. [PubMed: 11856655]

156. Watson NR, Studd JW, Savvas M, Baber RJ. The long-term effects of estradiol implant therapy for the treatment of premenstrual syndrome. Gynecol Endocrinol. 1990; 4:99-107. [PubMed: 2118709]

157. O’Brien P, Abukhalil I, Henshaw C. Premenstrual syndrome. Curr Obstet Gyneacol. 1995; 5:3035.

158. Domoney C, Panay N, Hawkins A, Studd JWW. Treatment of premenstrual syndrome with transdermal oestrogen. Int J Gynaecol Obstet. 2003; 83 (suppl 3):37. [PubMed: 14511870]

159. Bancroft J, Rennie D. The impact of oral contraceptives on the experience of perimenstrual mood, clumsiness, food craving and other symptoms. J Psychosom Res. 1993; 37:195-202. [PubMed: 8463994]

160. Graham CA, Sherwin BB. A prospective treatment study of premenstrual symptoms using a triphasic oral contraceptive. J Psychosom Res. 1992; 36:257-66. [PubMed: 1564678]

161. Sulak P, Scow R, Preece C, Riggs M, Kuehl T. Hormone withdrawal symptoms in oral contraceptive users. Obstet Gynecol. 2000; 95:261-66. [PubMed: 10674591]

162. Sulak P, Kuehl T, Ortiz M, Schull B. Acceptance of altering the standard 21-day/7-day oral contraceptive regimen to delay menses and reduce hormone withdrawal symptoms. Am J Obstet Gynecol. 2002; 186:1142-49. [PubMed: 12066088]

163. Halbreich U, Rojansky N, Palter S. Elimination of ovulation and menstrual cyclicity (with danazol) improves dysphoric premenstrual syndromes. Fertil Steril. 1991; 56:1066-69. [PubMed: 1743323] 
164. Watts JF, Butt WR, Edwards RL. A clinical trial using danazol for the treatment of premenstrual tensiohn. BJOG. 1987; 94:30-34.

165. Hahn PM, Van Vugt DA, Reid RL. A randomized, placebo-controlled, crossover trial of danazol for the treatment of premenstrual syndrome. Psychoneuroendocrinology. 1995; 20:193-99. [PubMed: 7899538]

166. Lam R, Carter D, Misri S, Kuan A, Yatham L, Zis A. A controlled study of light therapy in women with late luteal phase dysphoric disorder. Psychiatry Res. 1999; 86:185-92. [PubMed: 10482337]

167. Vellacott I, Shroff N, Pearce MY, Stratford ME, Akbar FA. A double-blind, placebo-controlled evaluation of spironolactone in the premenstrual syndrome. Curr Med Res Opin. 1987; 10:450 56. [PubMed: 3621990]

168. Aslaksen K, Falk V. Spironolactone in the treatment of premenstrual tension: A double-blind study of spironolactone $v s$ bendroflumethiazide and placebo. Curr Ther Res Clin Exper. 1991; 49:120.

169. Wyatt KM, Dimmock PW, Jones PW, Shaughn O'Brien PM. Efficacy of vitamin B-6 in the treatment of premenstrual syndrome: systematic review. BMJ (Clin Res Ed). 1999; 318:1375-81.

170. Schellenberg R. treatment for the premenstrual syndrome with agnus castus fruit extract: prospective, randomised, placebo controlled study. BMJ. 2001; 322:134-37. [PubMed: 11159568]

171. Budeiri D, Li Wan Po A, Dornan JC. Is evening primrose oil of value in the treatment of premenstrual syndrome? Control Clin Trials. 1996; 17:60-68. [PubMed: 8721802]

172. Walker A, De Souza M, Marakis G, Robinson P, Morris A, Bolland K. Unexpected benefit of sorbitol placebo in Mg intervention study of premenstrual symptoms: implications for choice of placebo in RCTs. Med Hypotheses. 2002; 58:213-20. [PubMed: 12018972]

173. Khine K, Rosenstein DL, Elin RJ, Niemela JE, Schmidt PJ, Rubinow DR. Magnesium (mg) retention and mood effects after intravenous $\mathrm{mg}$ infusion in premenstrual dysphoric disorder. Biol Psychiatry. 2006; 59:327-33. [PubMed: 16197921]

174. Sayegh R, Schiff I, Wurtman J, Spiers P, McDermott J, Wurtman R. The effect of a carbohydraterich beverage on mood, appetite, and cognitive function in women with premenstrual syndrome. J Am Coll Obstet Gynecol. 1995; 86:520-28.

175. Freeman EW, Stout AL, Endicott J, Spiers P. treatment of premenstrual syndrome with a carbohydrate-rich beverage. Int J Gynecol Obstet. 2002; 77:253-54.

176. Hunter MS, Ussher JM, Browne SJ, Cariss M, Jelley R, Katz M. A randomized comparison of psychological (cognitive behavior therapy), medical (fluoxetine) and combined treatment for women with premenstrual dysphoric disorder. J Psychosom Obstet Gynaecol. 2002; 23:193-99. [PubMed: 12436805]

177. Steege JF, Blumenthal JA. The effects of aerobic exercise on premenstrual symptoms in middleaged women: a preliminary study. J Psychosom Res. 1993; 37:127-33. [PubMed: 8463989]

178. Mira M, McNeil D, Fraser IS, Vizzard J, Abraham S. Mefenamic acid in the treatment of premenstrual syndrome. J Am Coll Obstet Gynecol. 1986; 68:395-98.

179. Facchinetti F, Fioroni L, Sances G, Romano G, Nappi G, Genazzani AR. Naproxen sodium in the treatment of premenstrual symptoms: a placebo-controlled study. Gynecol Obstet Investig. 1989; 28:205-08. [PubMed: 2695413]

180. Chuong CJ, Hsi BP. Effect of naloxone on luteinizing hormone secretion in premenstrual syndrome. Fertil Steril. 1994; 61:1039-44. [PubMed: 8194614] 
Search strategy and selection criteria

In this Seminar, we searched Medline (1950-2006) with the subject heading "premenstrual syndrome" and keywords of "premenstrual syndrome" and "premenstrual dysphoric disorder". Of the 3138 publications that we identified, we selected the most up-to-date publications as well as key reports in the field relevant to the phenomenology, pathophysiology, and treatment of moderate to severe PMS and PMDD. To ensure that important publications were reviewed, we searched the reference lists of articles as well as reviews. We incorporated additional publications after comments from peer reviewers. 
Panel: Clinical criteria for premenstrual dysphoric disorder

- In most menstrual cycles during the past year, at least five of the following symptoms should have been present for most of the last week of the luteal phase, remitted within a few days after onset of menses, and remained absent in the week after menses. At least one symptom must be 1,2,3, or 4:

1. Depressed mood or dysphoria

2. Anxiety or tension

3. Affect lability

4. Irritability

5. Decreased interest in usual activities

6. Concentration difficulties

7. Marked lack of energy

8. Marked change in appetite, overeating, or food cravings

9. Hypersomnia or insomnia

10. Feeling overwhelmed

11. Other physical symptoms—eg, breast tenderness, bloating

- Symptoms markedly interfere with work, school, social activities, or relationships

- Symptoms are not just an exacerbation of another disorder

- The first three criteria must be confirmed by prospective daily ratings for at least two consecutive menstrual cycles

Adapted from the Diagnostic and Statistical Manual IV (DSM IV). 


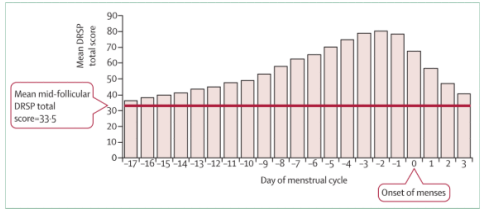

Figure 1. Timing of PMDD symptom severity across menstrual period DRSP=Daily Rating of Severity of Problems. Total symptoms were averaged for the corresponding day of the menstrual cycle. Day 14 indicates the beginning of the luteal phase. Day 1 is the first day of the following menstrual cycle. The follicular phase average score for the entire cohort was 33.5 and is indicated by a horizontal line. Adapted from Pearlstein et al, 2005. ${ }^{16}$ 


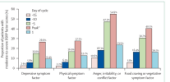

Figure 2. Severity of PMDD symptoms according to menstrual cycle stage DRSP=Daily Rating of Severity of Problems. *The symptom peak occurred on day -2 (ie, 2 days before onset of menses) for depressive symptoms; day -1 for physical symptoms; day 2 for anger, irritability, or tendency towards conflict; day -3 for food cravings. Mean symptom scores for each factor are shown. Adapted from Pearlstein et al, 2005. ${ }^{16}$ 
Table

Major strategies for treatment of premenstrual syndrome

\begin{tabular}{|c|c|c|}
\hline & Dose & Most important side-effects \\
\hline \multicolumn{3}{|l|}{$\underline{\text { Serotonin reuptake inhibitors }}$} \\
\hline Clomipramine ${ }^{111,112}$ & $50-75 \mathrm{mg}$ daily or for half cycle & $\begin{array}{l}\text { Dry mouth, sedation, sexual dysfunction, } \\
\text { nausea, jitteriness }\end{array}$ \\
\hline Citalopram ${ }^{113}$ & $20-40 \mathrm{mg}$ daily or for half cycle & Sexual dysfunction, nausea, jitteriness \\
\hline Escitalopram ${ }^{114}$ & $10-20 \mathrm{mg}$ daily of for half cycle & Sexual dysfunction, nausea, jitteriness \\
\hline Fluoxetine $e^{115-120}$ & $20-60 \mathrm{mg}$ daily or for half cycle & Sexual dysfunction, nausea, jitteriness \\
\hline Paroxetine ${ }^{121,125}$ & $20-30 \mathrm{mg}$ daily or for half cycle & Sexual dysfunction, nausea, jitteriness \\
\hline Paroxetine $-\mathrm{CR}^{122-124}$ & $12 \cdot 5-25.0 \mathrm{mg}$ daily or for half cycle & Sexual dysfunction, nausea, jitteriness \\
\hline Sertraline ${ }^{126-130,133,134}$ & $50-150 \mathrm{mg}$ daily or for half cycle & Sexual dysfunction, nausea, jitteriness \\
\hline Venlafaxine $^{131,132}$ & $50-200 \mathrm{mg}$ daily or for half cycle & Sexual dysfunction, nausea, jitteriness \\
\hline \multicolumn{3}{|l|}{ Hormonal interventions } \\
\hline $\begin{array}{l}\text { Ostradiol transdermally; }{ }^{135} \text { must be combined with } \\
\text { oral progestagen intermittently, or intrauterine } \\
\text { progestagen }\end{array}$ & $\begin{array}{l}200 \mu \mathrm{g} \text { oestradiol twice weekly via } \\
\text { patch; see references for doses of } \\
\text { progestagens }\end{array}$ & $\begin{array}{l}\text { Skin irritation, oral progestagen can cause } \\
\text { PMS-like symptoms (which is unlikely } \\
\text { with intrauterine progestagen) }\end{array}$ \\
\hline $\begin{array}{l}\text { Oestradiol subcutaneous implant }{ }^{136} \text { must be } \\
\text { combined with oral progestagen intermittently, or } \\
\text { intrauterine progestagen }\end{array}$ & $\begin{array}{l}100 \mu \mathrm{g} \text { subcutaneous implant of } \\
\text { oestradiol; see references for doses of } \\
\text { progestagens }\end{array}$ & $\begin{array}{l}\text { Mastalgia, PMS-like symptoms from oral } \\
\text { progestagen }\end{array}$ \\
\hline $\begin{array}{l}\text { GnRH agonists; }{ }^{38-41} \text { long-term treatment only in } \\
\text { rare cases; monitoring of bone density and "add- } \\
\text { back" oestrogen is mandatory; oestrogen must be } \\
\text { combined with oral progestagen intermittently, } \\
\text { intrauterine progestagen, or oral tibolone } \\
\text { continuously } 137\end{array}$ & $\begin{array}{l}\text { Depends on which GnRH agonist used: } \\
\text { see references; also see references for } \\
\text { doses of oestrogen plus progestagens or } \\
\text { tibolone }\end{array}$ & PMS-like symptoms from oral progestagen \\
\hline Drosperinone-ethinyl oestradiol ${ }^{138,139}$ & $\begin{array}{l}3 \mathrm{mg} \text { drosperinone plus } 20 \mu \mathrm{g} \text { ethinyl } \\
\text { oestradiol for } 24 \text { days }\end{array}$ & Breast pain \\
\hline
\end{tabular}

